\title{
STRUKTUR KOMUNITAS IKAN KARANG DI PERAIRAN TERUMBU KARANG TAMAN NASIONAL BUNAKEN, SULAWESI UTARA
}

\section{(Community structure of coral reef fish at Bunaken National Park, North Sulawesi)}

\author{
Fakhrizal Setiawan ${ }^{1}$, Janny D. Kusen ${ }^{2}$ dan Georis J.F. Kaligis ${ }^{2}$ \\ ${ }^{1}$ Program Pascasarjana, Universitas Sam Ratulangi, Manado, Sulawesi Utara. \\ ${ }^{2}$ Fakultas Perikanan dan Ilmu Kelautan Universitas Sam Ratulangi, Manado, Sulawesi Utara.
}

\begin{abstract}
Penelitian ini dilakukan di area Taman Nasional Bunaken (TNB) pada 6 lokasi dengan 26 tapał pengamatan. Ke 6 lokasi tersebut adalah Pesisir Selatan TNB, Pesisir Utara TNB, Pulau Bunaken, Pulau A Mahado Tua, Pulau Mantehage dan Pulau Nain. Penelitian ini mencatat adanya total 368 spesies yang berasal dari 46 famili ikan karang. Pengelompokan berdasarkan kategori ikan karang ikan indikator dijumpai dari famik Chaetodontidae sebanyak 30 spesies, ikan mayor grup dari 32 famili sebanyak 238 spesies dan ikah target dari 15 famili sebanyak 100 spesies. Nilai persentase tutupan karang dan kelimpahan ikan menunjukkan Pulau Bunaken paling baik dibandingkan lokasi lainnya. Struktur komunitas, dilihat dari indeks ekeldgi keanekaragaman (H') yang berkategori sedang, kemerataan (E) yang berkategori labil dan dominansi (C) yang berkategori rendah) menunjukkan kondisi komunitas ikan karang masih baik. Perbandingan antar lokasi nnenunjukkan tingkat kesamaan spesies ikan karang mengelompok di lokasi Pesisir Selatan TN Bunaken berbeda dengan lokasi lainnya.

Kata kunci: Taman Nasional Bunaken, terumbu karang, struktur kømunitas ikan karang, Sulawesi Utara

This study was conducted in Bunaken National Park (TNB) area on six locations with 26 observation sites. The locations were Southern shore of TNB, Northern shore of TNB, Bunaken island, Manado Tua island, Mantehage island and Nain island. As many as 368 speeies of 46 families of coral reef fish were recorded in this study. Grouping into categories, those fish weere 30 species indicator fish from Chaetodontidae family, 238 major group fish species from 32 families and 100 target fish species from 15 families. The coral coverage percentage and fish abundance showed that Bunaken Island has the best condition compared to other locations. Based on the characteristics ecologicat indiees such as medium diversity (H'), labile evenness (E) and low dominance, the condition of reef fish communities could be considered is good. Based on the similarity index, the group of fish species in the sbuthoshore of TNB was different from other locations.
\end{abstract}

Keywords: Bunaken National ark, coral reef, reef fish community structure, North Sulawesi

\section{PENDAHUTHAN}

Taman Nasional Bunaken (TNB) adalah kawasan pelestarianalam berbasis lautan yang dikelola oleh pemerintah dan ditetapkan berdasarkan SK. Menteri Kehutanan No.730/KPTS-II/1991 dengan luas 89.065 Ha. Adapun wilayah TNB meliputî kawasan pulau-pulau yakni Pulau Bunaken, Manado Tua, Siladen, Mantehage dan Nain, Pesisir Tongkaina, Tiwoho, serta wilayah pesisir Arakan-Wawontulap. Ekosistem terumbu karang di TNB selama kurun waktu 10 tahun terakhir mengalami tekanan yang tinggi. Beban limbah dan sampah yang di buang melalui Teluk Manado secara terus menerus, penambahan penduduk di dalam kawasan serta aktivitas pariwisata yang tidak ramah lingkungan memberikan andil bagi degradasi ekosistem terumbu karang di dalam kawasan TNB.
Namun disayangkan data dan informasi mengenai kondisi ekologis seluruh kawasan TNB sangat minim didapat sehingga diperlukan kajian mengenai kondisi status karang dan ikan karang. Kajian ekologis baik karang maupun ikan karangnya yang dilakukan sebanyak 26 stasiun diharapkan dapat mewakili seluruh lokasi TNB sehingga memberikan informasi lengkap guna pemanfaatan sumberdaya laut yang lestari dan berkelanjutan. Berkaitan dengan hal di atas, tujuan penelitian ini adalah untuk mengetahui keadaan ikan karang berdasarkan data ekologinya serta pola pengelompokan lokasi berdasarkan kemiripan populasi ikan karang. Diharapkan bermanfaat sebagai bahan informasi ilmiah mengenai ekosistem terumbu karang TNB serta pengelolaan dan upaya konservasi di dalamnya. 


\section{METODE PENELITIAN}

Penelitian ini dilakukan dari Juli-Oktober 2012. Metode pencatatan tutupan karang dan makro benthos, menggunakan transek titik yaitu point intercept transect (PIT) sepanjang 50 meter sebanyak 3 kali ulangan pada dua kedalaman yaitu dangkal (2-4 meter) dan dalam (8-10 meter) (Marnane et al. 2003). Ikan karang menggunakan metode sensus visual pada transek yang sama dengan karang, transek pengamatan menggunakan garis maya yang ditarik paralel dengan transek garis membentuk luasan persegi panjang. Transek jenis ini dikenal dengan transek sabuk (Hill \& Wilkinson, 2004). Analisis data tutupan karang: \% kemunculan komponen $=\sum$ tiap Komponen/100 (total komponen) X 100\%. Analisis ikan karang meliputi: kelimpahan komunitas terpilih dapat dihitung dengan rumus (Odum, 1993): $\mathrm{X}_{\mathrm{i}}=\mathrm{n}_{\mathrm{i}} / \mathrm{A}$, dengan Xi sebagai kelimpahan komunitas terpilih ke-i (individu/koloni per meter persegi), ni sebagai jumlah total ko- munitas terpilih pada stasiun pengamatan ke-i dan A sebagai luas transek pengamatan. Struktur komunitas ikan karang meliputi indeks keanekaragaman Shanon-Weiner: $\mathrm{H}^{\prime}=-\sum_{\mathrm{i}=1}^{\mathrm{s}}$ pi ln pi, indeks kesamaan: $\mathrm{E}=\mathrm{H}^{\prime} / \mathrm{H}_{\text {maks }}$ dan indeks dominansi: $\mathrm{D}=\sum_{\mathrm{i}=1}^{\mathrm{s}} \mathrm{pi}^{2}$ (Ludwig \& Reynolds, 1988). Untuk mengetahui tingkat pengelompokan berdasarkan kesamaan spesies ikan karang digunakan Indeks Bray-Curtis (Krebs, 1989): $\mathrm{B}=\frac{\sum\left(\mathrm{X}_{\mathrm{ij}}-\mathrm{X}_{\mathrm{ik}}\right)}{\sum\left(\mathrm{X}_{\mathrm{ij}}-\mathrm{X}_{\mathrm{ik}}\right)}$, dimana: $\mathrm{B}=$ pengukuran ketidaksamaan Bray-Curtis $X_{\mathrm{ij}}$, $\mathrm{X}_{\mathrm{ik}}=$ nomor individu dalam spesies i đalam tiap sampel, $i, j=$ baris dan kolom ke-1,2,3. Pengukuran indeks kesamaan Bray-Curtis dapat menggunakan rumus komplemen indeks 'pengukuran Bray-Curtis yaitu 1,0-B (Krebs, 1989). Hasil perhitungan indeks Bray Curis ditampilkan dalam bentuk dendrogram. Pengolahan data menggunakan perangkat lunak MVSP.

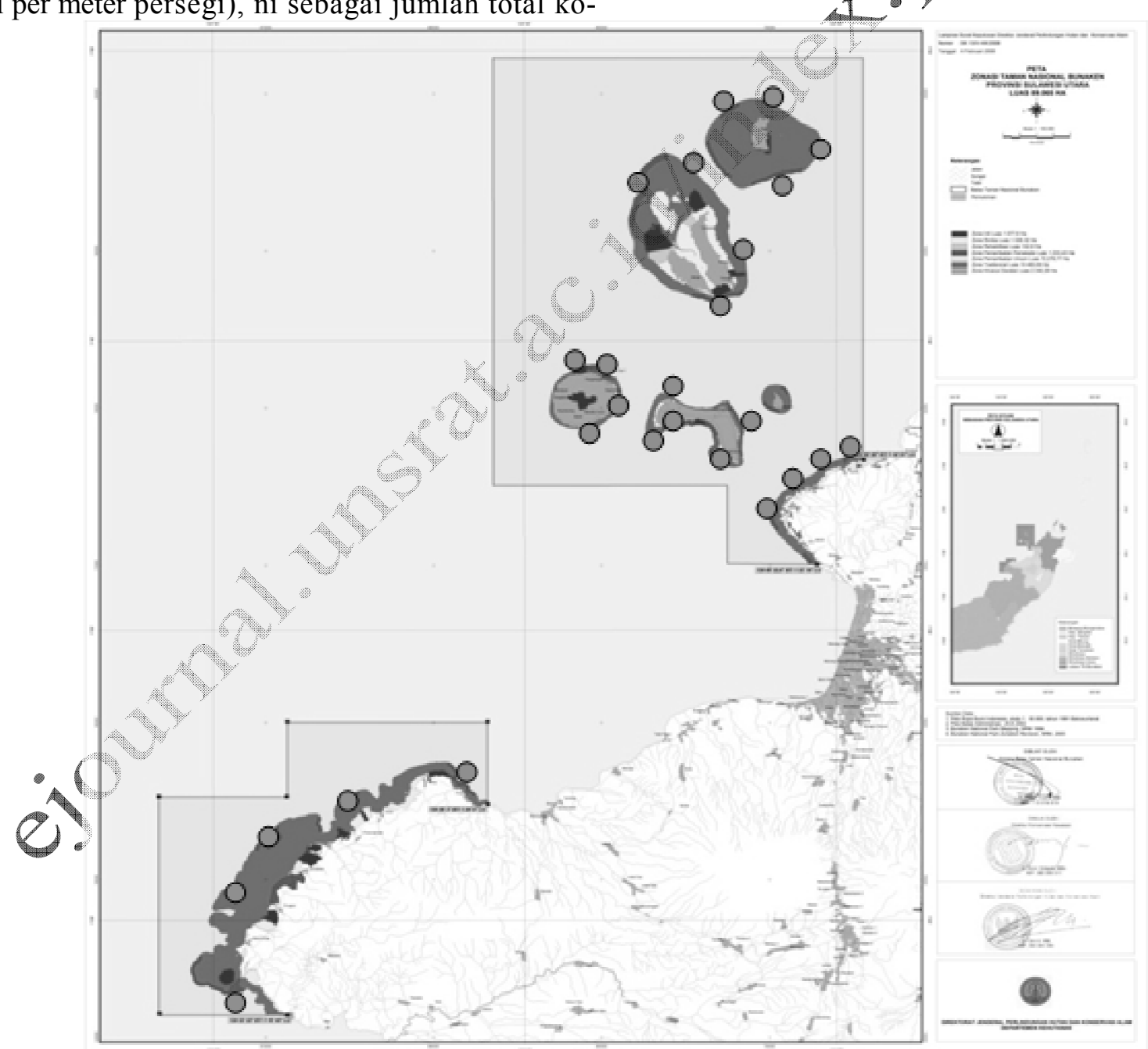

Gambar 1. Lokasi pengamatan di TNB (sumber peta TN. Bunaken).

Figure 1. Observation stations in TNB. 
Tabel 1. Persentase tutupan karang hidup di TNB.

Table 1. Percentage of live coral coverage in TNB.

\begin{tabular}{|c|c|c|c|c|c|c|}
\hline \multirow{2}{*}{$\begin{array}{c}\text { Lokasi } \\
\text { Pesisir Selatan TNB }\end{array}$} & \multirow{2}{*}{$\begin{array}{c}\text { Zonasi } \\
\text { Pariwisata }\end{array}$} & \multirow{2}{*}{\begin{tabular}{l}
\multicolumn{1}{c}{ Tapak } \\
Arakan
\end{tabular}} & \multicolumn{2}{|c|}{ Posisi Gografis } & \multirow{2}{*}{$\begin{array}{c}\text { Karang (\%) } \\
47,92\end{array}$} & \multirow{2}{*}{$\begin{array}{l}\text { Kondisi } \\
\text { Sedang }\end{array}$} \\
\hline & & & $01^{\circ} 21^{\prime} 04,73^{\prime \prime} \mathrm{LU}$ & $124^{\circ} 31^{\prime} 08,47^{\prime \prime} \mathrm{BT}$ & & \\
\hline & Pariwisata & Poopoh & $01^{\circ} 25^{\prime} 04,16^{\prime \prime} \mathrm{LU}$ & $124^{\circ} 37^{\prime} 46,72^{\prime \prime}$ BT & 6,50 & Buruk \\
\hline & Tradisional & Sondaken & $01^{\circ} 23^{\prime} 22,58^{\prime \prime} \mathrm{LU}$ & $124^{\circ} 33^{\prime} 37,86^{\prime \prime} \mathrm{BT}$ & 42,92 & Sedang \\
\hline & Pariwisata & Tatapaan & $01^{\circ} 17^{\prime} 29,16^{\prime \prime} \mathrm{LU}$ & $124^{\circ} 37^{\prime} 53,23^{\prime \prime}$ BT & 36,00 & Sedang \\
\hline & Tradisional & Wawantulap & $01^{\circ} 19^{\prime} 38,39^{\prime \prime} \mathrm{LU}$ & $124^{\circ} 30^{\prime} 28,47^{\prime \prime} \mathrm{BT}$ & 54,00 & Baik \\
\hline \multirow[t]{4}{*}{ Pesisir Utara TNB } & Tradisional & Batu Hitam & $01^{\circ} 41^{\prime} 57,54^{\prime \prime} \mathrm{LU}$ & $124^{\circ} 56^{\prime} 17,89^{\prime \prime}$ BT & 56,50 & Baik \\
\hline & Pariwisata & Dusun Bahowo & $01^{\circ} 39^{\prime} 35,64^{\prime \prime} \mathrm{LU}$ & $124^{\circ} 54^{\prime} 30,43^{\prime \prime}$ BT & 33,00 & Sedang \\
\hline & Tradisional & Kimabajo & $01^{\circ} 36^{\prime} 04,20^{\prime \prime} \mathrm{LU}$ & $124^{\circ} 50^{\prime} 43,20^{\prime \prime} \mathrm{BT}$ & 35,67 & Sedang \\
\hline & Pariwisata & Tanjung Pisok & $01^{\circ} 34^{\prime} 09,50^{\prime \prime} \mathrm{LU}$ & $124^{\circ} 48^{\prime} 06,20^{\prime \prime} \mathrm{BT}$ & 44,67 & Sedâng \\
\hline \multirow[t]{5}{*}{ Pulau Bunaken } & Pariwisata & Fukui & $01^{\circ} 36^{\prime} 34,27^{\prime \prime} \mathrm{LU}$ & $124^{\circ} 44^{\prime} 25,31^{\prime \prime}$ BT & 57,67 & \\
\hline & Tradisional & Mandolin & $01^{\circ} 38^{\prime} 02,71^{\prime \prime} \mathrm{LU}$ & $124^{\circ} 44^{\prime} 50,75^{\prime \prime} \mathrm{BT}$ & 46,58 & Sedang \\
\hline & Tradisional & Muka kampung & $01^{\circ} 35^{\prime} 40,34^{\prime \prime} \mathrm{LU}$ & $124^{\circ} 46^{\prime} 16,37^{\prime \prime}$ BT & & \\
\hline & Pariwisata & Pangalisan & $01^{\circ} 36^{\prime} 36,90^{\prime \prime} \mathrm{LU}$ & $124^{\circ} 46^{\prime} 58,60^{\prime \prime}$ BT & & Baik \\
\hline & Inti & Tawara & $01^{\circ} 36^{\prime} 59,35^{\prime \prime} \mathrm{LU}$ & $124^{\circ} 44^{\prime} 44,87^{\prime \prime}$ BT & & Baik \\
\hline \multirow[t]{4}{*}{ Pulau Manado tua } & Tradisional & Batu Layar & $01^{\circ} 37^{\prime} 47,50^{\prime \prime} \mathrm{LU}$ & $124^{\circ} 40^{\prime} 51,10^{\prime \prime}$ BT & & Buruk \\
\hline & Tradisional & EcoReef & $01^{\circ} 37^{\prime} 26,20^{\prime \prime} \mathrm{LU}$ & $124^{\circ} 42^{\prime} 53,50^{\prime \prime} \mathrm{BT}$ & 92 & Buruk \\
\hline & Pariwisata & Papindangan & $01^{\circ} 38^{\prime} 01,20^{\prime \prime} \mathrm{LU}$ & $124^{\circ} 43^{\prime} 08,40^{\prime \prime}$ BT & 63,33 & Baik \\
\hline & Inti & Tg. Kopi & $01^{\circ} 39^{\prime} 06,20^{\prime \prime} \mathrm{LU}$ & $124+4143,50=\mathrm{BA}$ & 40,33 & Sedang \\
\hline \multirow[t]{4}{*}{ Pulau Mantehage } & Pariwisata & Batu Gepe & $01^{\circ} 41^{\prime} 41,10^{\prime \prime} \mathrm{LU}$ & $124^{\circ} 46^{\prime} 49,90^{\prime \prime B ~}$ & 44,33 & Sedang \\
\hline & Tradisional & Buhias & $01^{\circ} 43^{\prime} 11,30^{\prime \prime} \mathrm{LU}$ & $124^{\circ} 46^{\prime} 41,30 \mathrm{~B}$ & 32,83 & Sedang \\
\hline & Tradisional & Pulau Paniki & $01^{\circ} 45^{\prime} 18,50^{\prime \prime} \mathrm{LU}$ & $124^{\circ} 45^{\prime} 54,20 \prime^{\prime \prime} \mathrm{B}$ & 17,67 & Buruk \\
\hline & Pariwisata & Tg. Jangkar & $01^{\circ} 46^{\prime} 22,40^{\prime \prime} \mathrm{LU}$ & $124^{\circ} 44^{3} 33,80^{\prime \prime}$ ВT & 25,50 & Sedang \\
\hline \multirow[t]{4}{*}{ Pulau Nain } & Pariwisata & Negeri & $01^{\circ} 47^{\prime} 27,20^{\prime \prime} \mathrm{LU}$ & A24 46) 12,30" BT & 22,42 & Buruk \\
\hline & Tradisional & Tatampi & $01^{\circ} 48^{\prime} 07,50^{\prime \prime} \mathrm{LU}$ & 24047 55,70" BT & 45,42 & Sedang \\
\hline & Pariwisata & Pintu masuk & $01^{\circ} 45^{\prime} 29,60^{\prime \prime} \mathrm{LU}$ & $124^{\circ} 46^{\prime} 52,40^{\prime \prime} \mathrm{BT}$ & 38,50 & Sedang \\
\hline & Tradisional & Timur Nain & $01^{\circ} 45^{\prime} 47,00^{\circ} \mathrm{L}$ & $124^{\circ} 48^{\prime} 03,70^{\prime \prime} \mathrm{BT}$ & 54,00 & Baik \\
\hline
\end{tabular}

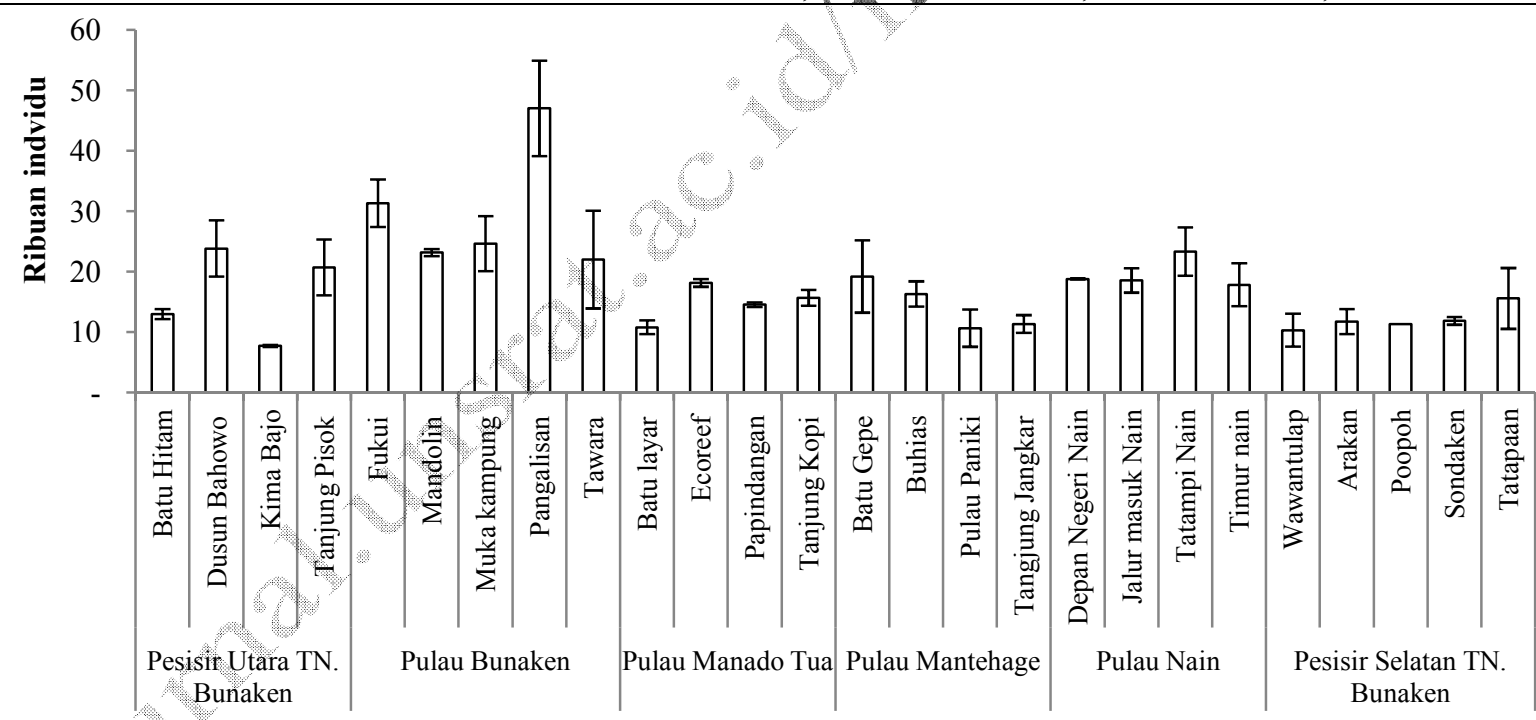

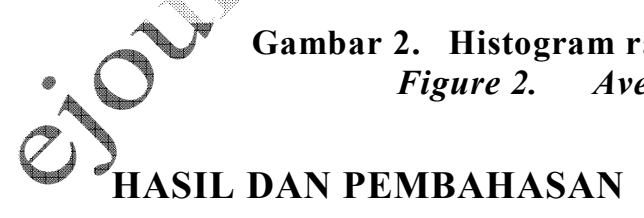

\section{Tutupan Karang}

Hasil pengamatan kondisi tutupan karang hidup TNB yang terdiri dari karang keras dan karang lunak berkisar antara $6,5-71 \%$ dengan ratarata 41,03\%. Berdasarkan KepMen Lingkungan Hidup No.4 tahun 2001, tentang kriteria baku kerusakan terumbu karang, maka kondisi terumbu karang tersebut berkisar antara kategori buruk hingga baik. Tutupan karang tertinggi sebesar $71 \%$ terdapat di tapak Pangalisan dan terendah sebesar 6,5\% terdapat di Poopoh. Tapak yang masuk dalam kategori baik (50-74,9\%) berjumlah 8 tapak, sedang (25-49,9\%) berjumlah 13 tapak dan tapak yang masuk kategori buruk (0-24,9\%) berjumlah 5 tapak (Tabel 1).

Pangalisan merupakan daerah di sisi timur Pulau Bunaken yang berkontur terumbu landai sehingga penetrasi cahaya dapat masuk dan 
merata di semua area, hal ini sesuai dengan pendapat Adrim (2007), bahwa hewan karang sangat tergantung pertumbuhannya pada sinar matahari.

Tidak ada satupun lokasi pengamatan dimana tutupan karangnya masuk dalam kategori sangat baik atau tutupannya lebih dari $75 \%$ (Tabel 1). Menurut Makatipu et al. (2010) rendahnya tutupan karang di beberapa lokasi di TNB disebabkan oleh pernah dilakukannya penangkapan ikan dengan cara merusak oleh masyarakat serta letaknya yang berada di daerah terbuka sehingga pada musim tertentu ombak sangat keras, sedangkan lokasi yang memiliki tutupan karang dalam kondisi baik berada pada daerah yang terlindung dan terletak dekat dengan Pulau Bunaken sehingga pengawasan lebih mudah.

\section{Ikan Karang}

Survey ikan karang di TNB pada 26 tapak mencatat 368 spesies dalam 46 famili. Famili dominan antara lain Pomacentridae (60 spesies), Labridae (58 spesies), Chaetodontidae (31 spesies), Acanthuridae (23 spesies), Scaridae (23 spesies), Serranidae (19 spesies), Balistidae (11 spesies), Bleniidae (10 spesies), Pomacanthidae (10 spesies), Holocentridae (9 spesies), dan sisanya kurang dari 9 spesies per famili.

\section{Kelimpahan dan Kategori Ikan Karang}

Kelimpahan ikan karang per tapak di TNB sangat beragam di mana kelimpahan tertinggitterdapat tapak Pangalisan sebesar $47.030 \mathrm{md} / \mathrm{Ha}$ dan terendah terdapat di tapak Kima Bajo sebesar $7.715 \mathrm{ind} / \mathrm{Ha}$ dengan rata-rata kelimpahan sebesar 18.054,44 ind/Ha (Gambar 2) Pangalisan yang terletak di sisi timur Pulau Bunaken merupakan zona pariwisata dan pemantatuan untuk aktivitas yang merusak terumbu karâng juga mudah dilakukan sehingga aktivitas penangkapan maupun wisata yang tidak ramah lingkungan dapat terpantau. Berdasarkan nilai pada tabel 1 , tutupan karang yang tinggi sejalan dengan tíngginya kelimpahan ikan.

Hasil rata-rata kelimpahan per lokasi tertingginterdapat di Pulau Bunaken sebesar 29.633 ind/Ha dan terendah di Pesisir Selatan TNB sebesar $12.160 \mathrm{ind} / \mathrm{Ha}$. Pulau Bunaken memiliki kelimpahan tertinggi dikarenakan pulau ini paling mudah pengawasannya. Setiap aktivitas merusak atau tidak ramah lingkungan paling mudah terpantau di Pulau Bunaken, hal ini pula yang diduga menyebabkan lokasi di Pesisir Selatan TNB yang jauh atau susah untuk dilakukan pengawasan memiliki kelimpahan terendah.
Selama penelitian telah diperoleh 3 kelompok kategori ikan karang yaitu ikan indikator dari famili Chaetodontidae sebanyak 30 spesies, ikan mayor grup 238 spesies dari 32 famili dan ikan target 100 spesies dari 15 famili.

\section{Ikan Indikator}

Famili Chaetodontidae tercatat sebanyak 30 spesies yang terdiri dari genus Chaetodon 25 spesies, genus Forcipiger 1 spesies, genus Hemitaurichthys 1 spesies dan genus Heniochus 3 spesies. Komposisi spesies ikan indikator tertinggiterdapat di tapak Muka Kampung sebanyak 42,8 individu yang didominasi oleh Hemisturichthys polylepis. Spesies ini mendominasi di beberapa lokasi penelitian karena umumnya ditemukan dalam jumlah besar. Komposisi spesies 7 kan indikator terendah terdapat di tapak Wawantulap sebanyak 9 individu (Gambar 3)

Tidak terlihat jelas keterkaitan antara tinggi rendahnya kelimpahan ikan indikator (total individu) dengantutupan karangnya. Menurut Adrim (2007), hat in diduga keterkaitannya dengan spesies Chateodontidae jenis tertentu saja. Spesies H. poly lepts berdasarkan Allen et al. (2003) termasuk tipe pemakan plankton atau planktifor dan hidupldi kolom perairan sehingga tidak berpengaruh langsung dengan tutupan atau kondisi terumbu ka- rang. Berdasarkan data, jumlah H. polylepis yang ditemukan totalnya sebanyak 1.051 individu dan jumlahnya tertinggi dibandingkan semua spesies ikan indikator yang ditemukan, hal inilah yang menyebabkan ketidaksesuaian antara kelimpahan ikan indikator dan tutupan karang hidup.

\section{Ikan Target}

Kelompok ikan target selama penelitian dijumpai sebanyak 100 spesies dalam 15 famili. Komposisi ikan target tertinggi terdapat di tapak Pangalisan sebesar 752 individu dan terendah terdapat di tapak Poopoh sebesar 27 individu. Ikan target yang memiliki kelimpahan tertinggi terdapat berasal dari famili Caesionidae (Caesio caerulaurea, Caesio cunning, Caesio lunaris, Caesio teres, Pterocaesio pisang, Pterocaesio tile dan Pterocaesio xanthonota). Jenis ikan ini biasa dikenal dengan ikan ekor kuning dan Lolosi dijumpai dalam jumlah besar (schooling).

\section{Grup Ikan Mayor}

Ikan mayor yang terdiri dari 238 spesies dari 32 famili merupakan kelompok ikan yang paling banyak dijumpai selama penelitian. Komposisi ikan mayor grup di semua lokasi mayoritas di- 
isi oleh famili Pomacentridae (60 spesies), Labridae (58 spesies) dan Acanthuridae (22 spesies) (Gambar 4). Famili Acanthuridae di beberapa lokasi di Indonesia beberapa jenisnya menjadi ikan target, namun di TNB, jenis ikan dari Famili ini hanya menjadi tangkapan sampingan bukan target utama. Spesies yang dominan antara lain Chromis ternatensis, Chromis dimidiata, Acanthochromis polyacanthus, Pomacentrus brachialis dan Cirrhilabrus solorensis.

\section{Struktur Komunitas Ikan Karang}

Hasil yang didapat selama penelitian menunjukkan indeks keanekaragaman berada pada kategori sedang hingga tinggi, berkisar antara 2,35-3,21 dengan nilai rata-rata 2,91 (Tabel 2). Nilai keanekaragaman ini menunjukkan bahwa keseluruhan lokasi masuk kategori sedang. Menurut Odum (1993) bahwa semakin besar nilai keanekaragaman (H') menunjukkan komunitas semakin beragam dan indeks keanekaragaman tergantung dari variasi jumlah spesies yang terdapat dalam suatu habitat. Nilai keanekaragaman tertinggi terdapat di tapak Jalur Masuk Nain $(3,21)$ dan terendah di tapak Wawantulap $(2,35)$ (Tabel 2).

Nilai indeks kemerataan (E) menunjukkan kestabilan sebuah komunitas. Nilai E yang semakin mendekati 1 menunjukkan komunitas semakin stabil dan jika semakin mendekati 0, maka komunitas semakin tertekan (Setyobudiandy et al, 2009 dalam Latucosina et al. 2012). Menurut Odum (1993) indeks kemerataan (E) menggămbarkan ukuran jumlah individu antar spesies dalam suatu komunitas ikan. Semakin merata sebaran individu antar spesies maka keseimbangan komunitas akan semakin baik. Indeks kemerataan tertinggi terdapat di tapak Timur Nain sebesar 0,74 dan terendah di tapak Pangalisan sebesar 0,46 dengan rata-rata 0,56. Nilai tersebut masuk dalam kategori tertekan hingga labil dan tidak ada satupun yang masuk dalam kategori stabil (Tabel 2). Nilai dominansi (C) berkisar antara $0-1$ di mana apabila nilainya mendekati 1 mentnjukkan terjadinya dominasi spesies, begitu juga jika nilainya mendekati 0 menandakan tidak ada dominasi oleh salah satu spesies (Setyobudiandy et al. 2009 dalam Latucosina et al. 2012). Nilai dominansi (C) tertinggi terdapat di tapak Wawantulap $(0,21)$ dan terendah di tapak Pulau Paniki $(0,06)$.

Hasil penelitian menunjukkan semua lokasi masuk dalam kategori dominansi rendah, hal ini menunjukkan tidak adanya dominansi oleh salah satu spesies ikan karang di lokasi penelitian. Hal ini sesuai dengan pendapat Odum (1993) di mana indeks keanekaragaman (H') dan kemerataan (E) bersifat terbalik dengan indeks dominansinya. Nilai $\mathrm{H}^{\prime}$ dan $\mathrm{E}$ yang tinggi menunjukkan tingkat dominansi yang rendah.

Tabel 2. Indeks keanekaragaman Shanon-Weiner (H'), indeks kemerataan (E) dan indeks dominansi (C).

Table 2. Shanon-Weiner diversity $\left(H^{\prime}\right)$, evenness (E) and dominance indies $(C)$.

\begin{tabular}{|c|c|c|c|c|}
\hline Lokasi & Nama Tapak & $\mathbf{H}$ & $\mathbf{E}$ & C \\
\hline \multirow{4}{*}{$\begin{array}{c}\text { Pesisir } \\
\text { Utara } \\
\text { TN Bunaken }\end{array}$} & Batu Hitam & 3,07 & 0,60 & 0,07 \\
\hline & Dusun Bahowo & 3,17 & 0,57 & 0,08 \\
\hline & Kima Bajo & 2,95 & 0,65 & 0,07 \\
\hline & Tanjung Pisok & 3,18 & 0,58 & 0,09 \\
\hline \multirow{5}{*}{$\begin{array}{c}\text { Pulau } \\
\text { Bunaken }\end{array}$} & Fukui & & 0,51 & 0,08 \\
\hline & Mandolin & & 0,52 & 0,12 \\
\hline & Muka kampung & 2,95 & 0,50 & 0,10 \\
\hline & Pangalisan & 2,87 & 0,46 & 0,12 \\
\hline & Tawara & 2,87 & 0,51 & 0,10 \\
\hline \multirow{4}{*}{$\begin{array}{l}\text { Pulau } \\
\text { Manado } \\
\text { Tua }\end{array}$} & Batu laya & 2,90 & 0,58 & 0,08 \\
\hline & Ecoreef & 3,12 & 0,57 & 0,07 \\
\hline & Papindangan & 2,43 & 0,48 & 0,21 \\
\hline & Tanifung Kopi & 3,01 & 0,57 & 0,08 \\
\hline \multirow{8}{*}{$\begin{array}{l}\text { Pulau } \\
\text { Ianteha } \\
\text { Pulau }\end{array}$} & BatulGepe & 3,03 & 0,55 & 0,10 \\
\hline & Buhias & 3,10 & 0,59 & 0,09 \\
\hline & Pulau Paniki & 3,15 & 0,64 & 0,06 \\
\hline & Tanjung Jangkar & 3,19 & 0,63 & 0,06 \\
\hline & Depan Negeri Nain & 2,69 & 0,50 & 0,15 \\
\hline & Jalur masuk Nain & 3,21 & 0,59 & 0,07 \\
\hline & Tatampi Nain & 2,82 & 0,51 & 0,14 \\
\hline & Timur Nain & 2,80 & 0,74 & 0,12 \\
\hline \multirow{5}{*}{$\begin{array}{c}\text { Pesisir } \\
\text { Selatan } \\
\text { TN Bunaken }\end{array}$} & Wawantulap & 2,35 & 0,52 & 0,21 \\
\hline & Arakan & 2,66 & 0,55 & 0,10 \\
\hline & Poopoh & 2,86 & 0,56 & 0,10 \\
\hline & Sondaken & 2,46 & 0,50 & 0,14 \\
\hline & Tatapaan & 2,91 & 0,57 & 0,10 \\
\hline
\end{tabular}

\section{Kesamaan Spesies Ikan Karang}

Pada taraf penskalaan dendrogram $49,7 \%$, yang merupakan nilai rata-rata dari indeks similaritas antar stasiun, diperoleh 4 kelompok komunitas. Kelompok komunitas pertama adalah tapak Poopoh, kelompok habitat kedua adalah Arakan dan Wawantulap, kelompok komunitas ketiga adalah Sondaken dan Kima bajo, kelompok komunitas ke empat adalah Tanjung Jangkar, Negeri Nain, Tatampi Nain, Batu Layar, Timur Nain, Tatapaan/ Popareng, Papindangan, Tawara, Pangalisan, Muka Kampung, Tanjung Kopi, Mandolin, Jalur Masuk Nain, Fukui, Ecoreef, Pulau Paniki, Buhias, Dusun Bahowo, Tanjung Pisok, Batu Hitam dan Batu Gepe (Gambar 3).

Pengelompokan ini menunjukkan bahwa terdapat perbedaan komposisi spesies ikan karang antar grupnya. Terlihat pengelompokan grup 1 hingga grup 3 umumnya berada di Pesisir Selatan TNB. Pengelompokkan ini diduga karena lokasi di Pesisir Selatan TNB kondisi habitatnya banyak 
yang telah rusak sehingga ikan karang yang mendiami area tersebut jauh berkurang.

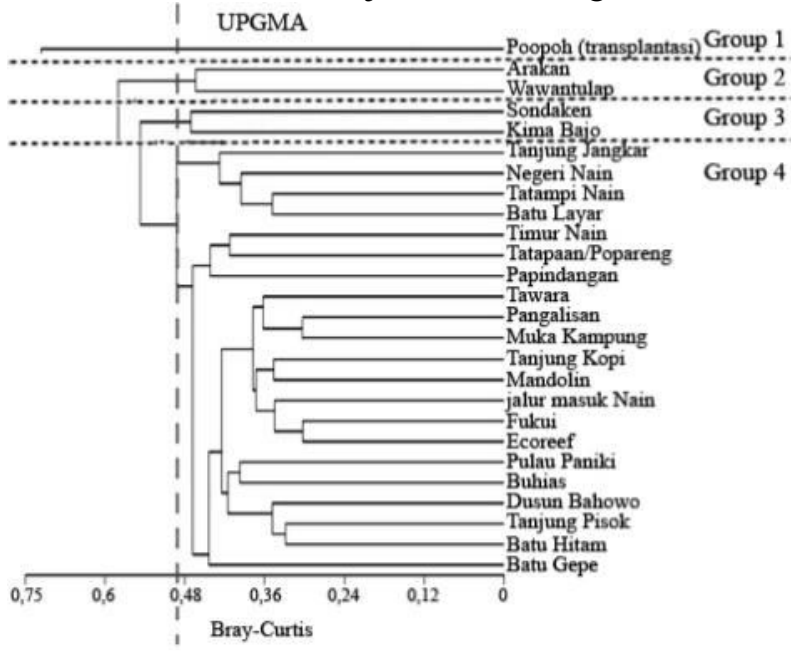

Gambar 3. Dendrogram ke 26 tapak berdasarkan kelimpahan spesies ikan karang.

Figure 3. Dendrogram to 26 tread based on the abundance of reef fish species

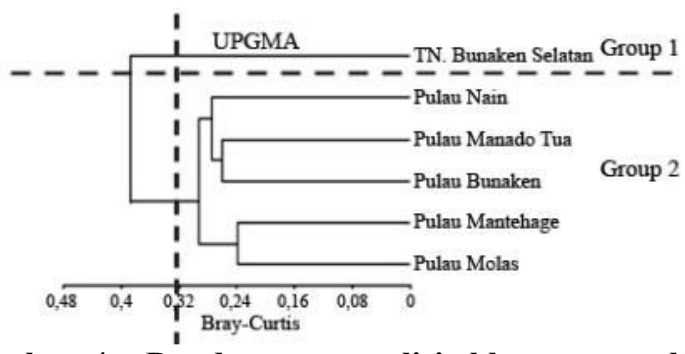

Gambar 4. Dendrogram analisis klaster pengelompokan ikan karang per pulau/Tokasi di daerah terumbu karang TNB.

Figure 4. Dendrogram cluster analysis grouping of reef fish each island/location in the coral reef park.

Hasil yang lebih jelas dapat terlihat pada tingkat pengelompokan berdasarkan pulau/lokasi dimana pada taraf penskalaan $32 \%$, didapat dua pengelompokan ikan karang (Gambar 4). Pertama kelompok Pesisir Selatan TNB dan kedua terdiri dari Pulau Nain, Pulau Manado Tua, Pulau Bunaken, Pulau Mantehage dan Pesisir Utara TNB.

Pengelompokan ini diduga karena lokasi di Pesisir Selatan TNB kondisi habitatnya banyak yang felah rusak sehingga ikan karang yang mendiami area tersebut jauh berkurang. Hal ini lah yang mungkin menyebabkan terjadi dua pengelompokan spesies ikan karang.

\section{KESIMPULAN}

Terdapat 368 spesies dalam 46 famili yang terdiri atas 3 kelompok kategori ikan karang yaitu ikan indikator dari famili Chaetodontidae se- banyak 30 spesies, ikan mayor sebanyak 238 spesies dari 32 famili dan ikan target sebanyak 100 spesies dari 15 famili. Kelimpahan ikan Pulau Bunaken paling tinggi dibandingkan lokasi lainnya. Struktur komunitas ikan karang masih baik, keanekaragaman di semua tapak masuk kategori sedang, kemerataan berkategori labil dan dominasi berkategori rendah. Tingkat kesamaan spesies ikan karang mengelompokan lokasi di Pesisir Selatan TNB berbeda dengan lokasi lainnya.

\section{UCAPAN TERIMAKASIH}

Penelitian ini dapat terlaksana atas bantuan penuh dari Balai TNB antukitu penulis menghaturkan terima kasih kepada Bpk. Ir. Edy Sutiyarto selaku Kepala Balai TNB atas kepercayaan yang diberikan untukpenyelenggaraan kegiatan penelitian tersebut. Penulis juga mengucapkan terima kasih kepada para Pandu dari Balai TNB dan berbagai pihak yang telah membantu terlaksananya penelitian ini.

\section{Daftar pustaka}

Adrim M.2007. Komunitas Ikan Karang di Perairan Pulau Enggano, Provinsi Bengkulu. Pusat Penelitian OseanologiLIPI. Jurnal 33. p 139-158.

Allen G, Steene R, Hulmann P and Deloach N. 2003. Reef Fish Tropical Pacific Identification. New World Publ. Inc. Jackson ville. Florida. USA.

Hill J and Wilkinson C. 2004. Methods for Ecological Monitoring of Coral Reefs: A Resource for Managers. Australian Institute of Marine Science and Reef Check, Australia.

Krebs ChJ. 1989. Ecological Methodology. Univ. of British Columbia. Harper Collins Publisher. 645 p.

Latuconsina H, Nessa MN. dan Rappe RA. 2012. Komposisi Spesies dan Struktur Komunitas Ikan Padang lamun di Perairan Tanjung Tiram-Teluk Ambon Dalam. Jurnal Ilmu dan Teknologi Kelautan Tropis, Vol.4 No.1. p 35-46.

Ludwig JA. and Reynolds JF. 1988. Statistical Ecology: A Primer on Methods and Computing. John Wiley \& Sons, New York: xviii +337 p.

Makatipu PC., Peristiwady T. dan Leuna M. 2010. Biodiversitas Ikan target di Terumbu Karang Taman Nasional Bunaken, Sulawesi Utara. Oseanologi dan Limnologi di Indonesia. Jurnal.Vol. 36 (3). LIPI. Jakarta.

Marnane et al. 2003. Laporan Teknis Survey 2003-2004 di Kepulauan Karimunjawa, Jawa tengah. WCS. 75 p.

Odum EP. 1993. Dasar-Dasar Ekologi. Gadjah Mada Univ. Press. Yogyakarta. 697 p. 